\title{
Pengembangan Home Industri Berbasis Sumber Daya Home Industry Improvement Based On Resources View
}

\author{
Deviya Aprilman \\ Politeknik Raflesia. \\ Email : daprilman@yahoo.com
}

\begin{abstract}
ABSTRAK
Industri merupakan faktor penentu terhadap kemajuan bangsa, kalau industri maju maka negara akan menjadi maju, kemajuan industri tergantung dari kemajuan teknologi, untuk memenuhi kebutuhan produk dan jasa maka industri harus berkembang. Home industri merupakan cikal bakal kemajuan suatu daerah khususnya didaerah rejang lebong dan berbasis industri kopi.

Penelitian ini dilakukan untuk melihat tingkat pelaksanaan dan kesiapan industri untuk mengembangkan home industri berbasis sumber daya, guna untuk menyediakan layanan dan memenui kebutuhan konsumen. Dalam pengmbangan industri ini menggunakan metode VRIO (analisis internal berbasis sumber daya). Untuk menghubungkan faktor internal dan eksternal menggunakan analisa SWOT kemudian diolah menggunakan aplikasi AHP dalam menetukan bobot penilaian, dari hasil ini untuk menetukan strategi dalam mengembangkan home industri di kab. Rejang Lebong
\end{abstract}

Kata kunci: Home industri, VRIO, SWOT, AHP

\section{PENDAHULUAN}

Seiring berkembangnya kebutuhan akan produk kopi yang baik maka penyedia atau home industri harus mampu memberikan kualitas produk sesuai dengan yang diinginkan oleh konsumen, oleh karena itu home industri sebagai penyedia produk harus memberikan jaminan produk sesuai standar produk nasional.

Home industri adalah suatu unit usaha/perusahaan dalam skala kecil yang bergerak dalam bidang industri tertentu. Biasanya usaha ini hanya menggunakan satu atau dua rumah sebagai pusat produksi, administrasi dan pemasaran sekaligus secara bersamaan. Bila dilihat dari modal usaha dan jumlah tenaga yang diserap tentu lebih sedikit daripada perusahaan-perusahaan besar pada umumnya.

Peluang berkembangnya home industri menjadi besar sangat tergantung dari berbagai faktor terutama sumber daya manusia, berhubungan dengan prospek usaha dalam mengahadapi persaingan antar kegiatan ekonomi untuk memenuhi kebutuhan permintaan.

\section{LANDASAN TEORI}

\section{a. Merancang Strategi}

1. Pengertian Strategi

Hasil dari tahapan telaah diri adalah serangkaian keputusan tentang prioritas pengembangan sekolah selama kurun waktu siklus perencanaan yang disusun. Prioritas-prioritas itu dapat dinyatakan sebagai tujuan strategis. Keputusan tidak akan berdampak apapun jika tidak diwujudkan dalam tindakan yang bersifat strategis.

Strategi adalah "suatu pertimbangan dan pemikiran yang logis, analitis serta konseptualisasi hal-hal penting atau prioritas (baik dalam jangka panjang, pendek maupun mendesak), yang dijadikan acuan untuk menetapkan langkah-langkah, tindakan, dan caracara (taktik) ataupun kiat (jurus-jurus) yang harus dilakukan secara terpadu demi terlaksananya kegiatan operasional dan penunjang dalam menghadapi tantangan yang harus ditangani dengan sebaik-baiknya sesuai dengan tujuan ataupun sasaran-sasaran dan hasil (output) yang harus dicapai serta kebijaksanaan yang sudah ditetapkan sebelumnya. Strategi paling baik didefinisikan sebagai "melakukan hal yang benar" sementara taktik adalah "melakukan segalanya dengan benar". Strategi yang baik datang dari cara berfikir yang benar. Dalam mengembangkan strategi, dua pertanyaan mendasar harus dijawab, yaitu:Apa yang harus dilakukan?

a. Bagaimana melakukannya?

b. Bagaimana melakukannya?

Daft (1988) mendefinisikan strategi sebagai rencana tindakan yang berupa penentuan alokasi sumber daya dan kegiatan untuk bergelut dengan lingkungan dan membantu organisasi mencapai tujuannya. 
Pada level tertinggi dalam sebuah struktur organisasi, tingkat sekolah misalnya, strategi yang digunakan disebut dengan grand strategy. Strategi ini diartikan sebagai rencana umum mengenai tindakan utama malalui mana sebuah organisasi berniat untuk mencapai tujuan jangka panjangnya.

\section{b. Macam-Macam Strategi}

Terdapat berbagai opsi strategi yang dapat dipilih oleh sekolah dalam rangka mencapai tujuan strategisnya. Beberapa tipologi strategi tersebut diuraikan secara singkat sebagai berikut.

a) Kategorisasi Grant Strategy

Grant strategy dibedakan menjadi tiga kategori: pertumbuhan, stabilitas, dan penghematan atau retrenchment.

Pertumbuhan. Pertumbuhan atau growth dapat didorong dari dalam dengan cara meningkatkan investasi dalam bentuk peningkatan kesempatan akses masyarakat atau meningkatkan diversifikasi layanan pendidikan atau meningkatkan standar kualitas layanan di atas standar yang berlaku umum, standar nasional misalnya.

Stabilitas. Stabilitas, kadang-kadang disebut strategi berhenti sesaat (pause strategy), berarti bahwa sekolah ingin tetap berada pada kondisinya sekarang atau tumbuh perlahanlahan dan tetap terkendali. Ketika sebuah sekolah telah mengalami pertumbuhan yang pesat dan berhasil mencapai puncak visi yang diinginkan, sekolah itu biasanya memfokuskan diri pada strategi stabilitas untuk mengintegrasikan semua unit yang ada agar tetap berada pada kondisi puncak itu dengan terus meningkatkan efisiensi.

Penghematan. Penghematan berarti bahwa sekolah melakukan pengurangan layanan pendidikan dengan mempersempit jenis program pendidikan yang diberikan. Cara ini dapat dilakukan dengan menghentikan sejumlah program kurikuler yang bersifat pengayaan atau menghentikan sejumlah kegiatan ekstra kurikuler tidak diminati siswa atau mengurangi jumlah siswa yang diterima. Hal ini tentu akan berdampak pada pengurangan sumber daya yang diinvestasikan, baik SDM maupun sumberdaya lainnya.

b) Tipologi Strategi Adaptif dari Miles dan Snow Terdapat empat tipologi organisasi yang digunakan dasar dalam mengelompokkan strategi pengembangan oleh Miles dan Snow, yaitu prospector, defendor, analyzer, dan reactor. Hubungan antara masing-masing tipologi ini dengan strategi, kondisi lingkungan eksternal, dan karakteristik organisasi dirangkum pada Tabel 2.1

Tabel 2.2 : Tipologi Strategi Adaptif Menurut Miles dan Snow

\begin{tabular}{|l|l|l|l|}
\hline $\begin{array}{l}\text { Tipologi } \\
\text { Organisasi }\end{array}$ & Strategi & Lingkungan & $\begin{array}{l}\text { Karakteristik } \\
\text { Organisasi }\end{array}$ \\
\hline Prospector & $\begin{array}{l}\text { Inovasi, } \\
\text { Mencari Peluang Pasar } \\
\text { Baru, } \\
\text { Tumbuh } \\
\text { Ambil Resiko }\end{array}$ & $\begin{array}{l}\text { Dinamis } \\
\text { Tumbuh }\end{array}$ & $\begin{array}{l}\text { Kreatif } \\
\text { Inovatif } \\
\text { Fleksible } \\
\text { Desentralisasi }\end{array}$ \\
\hline Defendor & $\begin{array}{l}\text { Melindungi teritorialnya } \\
\text { Penghematan } \\
\text { Mempertahankan } \\
\text { pangsa pasar yang } \\
\text { dimiliki }\end{array}$ & Stabil & $\begin{array}{l}\text { Kontrol ketat } \\
\text { Sentralisasi } \\
\text { Efisiensi produksi } \\
\text { Overheadrendah }\end{array}$ \\
\hline Analyser & $\begin{array}{l}\text { Mempertahankan pasar } \\
\text { yang ada disertai inovasi } \\
\text { sekedamya }\end{array}$ & $\begin{array}{l}\text { Perubahan tingkat } \\
\text { menengah }\end{array}$ & $\begin{array}{l}\text { Kontrol dan } \\
\text { fleksibilitasketat } \\
\text { Produksi yang efisien } \\
\text { Kreativitas }\end{array}$ \\
\hline Reactor & $\begin{array}{l}\text { Tidak memiliki strategi } \\
\text { yangjelas } \\
\text { Bereaksi terhadap } \\
\text { kondisi-kondisi spesifik } \\
\text { Mengambang, mengalir } \\
\text { mengikuti arus }\end{array}$ & Kondisi apapun & $\begin{array}{l}\text { Pendekatan } \\
\text { organisasional tidak } \\
\text { jelas } \\
\text { Bergantung pada } \\
\text { kebutuhan sesaat }\end{array}$ \\
\hline
\end{tabular}

c) Strategi Kompetitif dari Porter

Michael E. Porter meneliti sejumlah strategi pada organisasi bisnis dan menganjurkan tiga strategi yang efektif pada tingkat manajemen menengah: diferensiasi (differebtiation), kepemimpinan berbiaya (cost leadreship), dan fokus.

Diferensiasi. Strategi ini mencakup usahausaha untuk membuat semua proses dan hasil pendidikan berbeda dengan sekolah yang lain. Sekolah dapat memanfaatkan promosi, programprogram pendidikan yang unik, standar kualitas yang lebih unggul, piranti teknologi yang khusus sehingga dihasilkan lulusan yang memiliki kompetensi yang bersifat khas, unik dan memiliki keunggulan kompetitif. Tentu saja keunikan dan kekhasan itu harus tetap pada kerangka visi, misi, tujuan, dan kebijakan-kebijakan pendidikan yang berlaku secara nasional, regional, lokal, maupun sekolah itu sendiri.

Kepemimpinan Pembiayaan (Cost Leadership). Dengan strategi ini berarti sekolah sacara agresif menggunakan sumber daya yang efisien, berusaha mengurangi anggaran, dan memperketat pengendalian anggaran agar pelaksanaan pendidikan lebih efisien dibandingkan lembaga lain yang sejenis.

d) Strategi Berbasis Analisis SWOT

Analisis SWOT merupakan sebuah metode untuk menguji strategi-strategi yang potensial yang dikembangkan atas dasar kekuatan, kelemahan, peluang dan ancaman. Melalui 
pengombinasian masing-masing unsur dan data yang luas yang telah trekumpul sebagai hasil analisis dapat berfungsi sebagai pemicu diskusi dan perbaikan strategi yang selama ini telah digunakan atau mengembangkan strategi-strategi baru. Matrik SWOT dapat membantu pengembangan strategi dengan menggunakan alat SWOT Analysis ini.

Matrik SWOT pada dasarnya merupakan daftar dari kekuatan, kelemahan, peluang, ancaman, serta kombinasi dari Strengths (S) dan Opportunities (O), Strengths (S) dan Threats (T), Weaknesses (W) dan Opportunities (O), Weaknesses (W) dan Threats (T). Terdapat empat pilihan strategi dalam matrik SWOT: competition, mobilization, investment/divestemen, dan damage control.

1) Strategi competition diterapkan apabila sekolah berada dalam posisi yang kuat dan banyak peluang yang teridentifikasi $(\mathrm{S}-\mathrm{O})$. Strategi ini merupakan pemanfaatan peluang berdasarkan kekuatan yang dimiliki.

2) Strategi mobilization dipilih apabila organisasi memiliki kekuatan yang cukup, tetapi diluar sana banyak ancaman yang harus dihadapi (S-T). Dengan kata lain, organisasi harus menanggulangi ancaman dengan memanfaatkan kekuatan yang ada.

3) Strategi investment/divestment diambil apabila organisasi dalam kondisi yang lemah akan tetapi banyak peluang yang tersedia (W-O). Dengan strategi ini organisasi memanfaatkan peluang yang ada untuk meningkatkan kekuatannya.

4) Strategi damage control dipakai apabila organsasi berada pada kondisi lemah dan harus banyak menghadapi ancaman (W-T). Dengan strategi ini organisasi harus menekan kelemahan dan ancaman secara bersama-sama.

\section{c. Sumber Daya}

Keunggulan kompetitif perusahaan ditentukan oleh sumber dayanya. Sumber daya adalah input-input dalam proses produksi perusahaan. Ruang lingkup sumber daya mencakup spektrum fenomena individual, sosial dan organisasi. Keunggulan kompetitif pada kenyataannya diciptakan melalui kumpulan beberapa sumber daya yang unik untuk itu perlu diidentifikasi kekuatan dan kelemahan sumber perusahaan dan perlunya kekompakan sumber daya perusahaan dari segi kekuatan dan kelemahannya.
Sebagian sumber daya berwujud, sementara sebagian lainnya tidak berwujud. Sumber daya berwujud (tangible asset) adalah aktiva-aktiva yang dapat dilihat dan diukur. Peralatan, produksi, pabrik-pabrik manufaktur dan struktur pelaporan formal adalah contoh dari sumber daya berwujud. Sumber daya tidak berwujud (intangible asset) meliputi aktiva-aktiva yang berurat akar dalam sejarah perusahaan dan telah terakumulasi sepanjang waktu.

\section{Sumber Daya}

Keunggulan kompetitif perusahaan ditentukan oleh sumber dayanya. Sumber daya adalah input-input dalam proses produksi perusahaan. Ruang lingkup sumber daya mencakup spektrum fenomena individual, sosial dan organisasi. Keunggulan kompetitif pada kenyataannya diciptakan melalui kumpulan beberapa sumber daya yang unik untuk itu perlu diidentifikasi kekuatan dan kelemahan sumber perusahaan dan perlunya kekompakan sumber daya perusahaan dari segi kekuatan dan kelemahannya.

Sebagian sumber daya berwujud, sementara sebagian lainnya tidak berwujud. Sumber daya berwujud (tangible asset) adalah aktiva-aktiva yang dapat dilihat dan diukur. Peralatan, produksi, pabrik-pabrik manufaktur dan struktur pelaporan formal adalah contoh dari sumber daya berwujud. Sumber daya tidak berwujud (intangible asset) meliputi aktiva-aktiva yang berurat akar dalam sejarah perusahaan dan telah terakumulasi sepanjang waktu.

Tabel 2.3. Sumber Daya Berwujud

\begin{tabular}{|c|c|}
\hline Sumber Daya Berwujud & \\
\hline Sumber daya keuangan & $\begin{array}{l}\text { - Kapasitas perusahaan untuk meminjam } \\
\text { - Kemampuan perusahaan untukmenghasilkan } \\
\text { dana internal }\end{array}$ \\
\hline Sumber daya organisasi & $\begin{array}{l}\text { - Struktur pelaporan formal perusahaan dan } \\
\text { perencanaan formalnya, sistem kontrol dan } \\
\text { sistem koordinasi } \\
\text { - Kecanggihan dan lokasi pabrik dan peralatan } \\
\text { perusahaan }\end{array}$ \\
\hline Sumber daya fisik & - Akses ke bahan mentah \\
\hline Sumber daya teknologi & $\begin{array}{l}\text { - Persediaan teknologi, seperti hak paten, hak } \\
\text { cipta, merek dagang, dan rahasia dagang }\end{array}$ \\
\hline
\end{tabular}

Sumber: Diadaptasi dari J.B Barney, 1991, Film resources and Sustained competitive advantage, Journal of management,17:101;R.M.Grant, 1991, Contemporary Strategy Analysis(Combridge, U.K.:Black Business),100-102.

Tabel 2.4. Sumber Daya Tidak Berwujud 


\begin{tabular}{|l|l|}
\hline Sumber Daya Tldak Berwujud & \\
\hline Sumber daya manusia & - Imu pengetahuan \\
& - Kepercayaan \\
\hline Sumber daya inovasi & - Kapabilitas manajerial \\
& - Rutin organisasi \\
\hline Sumber daya reputasi & - Gagasan \\
& - Kapabilitas saintifik \\
& - Kapabilitas untuk melakukan inovasi \\
\hline & - Raputasi dengan para pelanggan \\
& - Nama merek \\
& - Persepsi terhadap kualitas, daya tahan, \\
& - Ran reliabilitas produk \\
\hline
\end{tabular}

Sumber:Diadaptasi dari R.Hall, 1992, The Strategic of intangible resources, Strategic Management Journal, 13:136-139;R.M. Grant, 1991,Contemporary Strategic Analysis (Co,bridge,U.K:Blackwell Business),101-104.

Sumberdaya merupakan sebuah aset, kompetensi, proses, keahlian, atau pengetahuan yang dikuasai oleh perusahaan. Sumberdaya merupakan sebuah kekuatan jika hal tersebut membawa perusahaan memiliki sebuah keunggulan bersaing. Sumberdaya ini merupakan sesuatu yang dilakukan perusahaan atau potensi yang dimiliki untuk melakukan sesuatu dengan relatif terperinci yang berhubungan dengan keberadaan atau pesaing berpotensi. Sumberdaya adalah suatu kelemahan jika merupakan hal yang dilakukan oleh perusahaan dengan buruk atau tidak memiliki kapasitas untuk melakukan sesuatu meskipun pesaingnya memiliki kapasitas tersebut. Barney, dalam analisis kerangka VRIO yang dimilikinya, mengajukan 4 pertanyaan untuk mengevaluasi sumberdaya andalan setiap perusahaan :

1. Nilai (Value): Apakah hal ini menentukan keunggulan bersaing ?

2. Kelangkaan (Rareness) : Apakah kompetitor lain memiliki ini ?

3. Kemampuan dapat ditiru (Imitability): Apakah mahal untuk ditiru orang lain ?

4. Organisasi : Apakah perusahaan diorganisir untuk mengeksploitasi sumberdaya?

\section{d. Keunggulan Bersaing}

Selanjutnya Grant menyatakan bahwa langkah 3 adalah menilai potensi dan kapabilitas dari segi potensi adalah keunggulan kompetitif yang dapat bertahan dan kelayakan hasil kembaliannya. Banyak hal yang bias dilakukan untuk mencapai keunggulan bersaing. Antara lain, pendapat yang yang sering muncul adalah dengan menemukan dan mengembangkan suatu core competency atau kompetensi inti. Kompetensi berkaitan dengan skill, knowledge dan teknologi know how yang memberikan keunggulan khusus pada poin tertentu dari rantai nilai yang apabila digabungkan dengan "strategic process" akan menggabungkan rantai membentuk "core capability" (Crown, 2002).

Pengamatan dan penganalisaan lingkungan eksternal terhadap peluang dan ancaman tidaklah cukup untuk menentukan keuntungan bersaing (competitive advantage) sebuah organisasi. Seorang analis harus juga mengamati lebih jauh mengenai bagaimana perusahaan tersebut dapat mengindentifikasi faktor-faktor strategi internalKekuatan dan kelemahan yang mungkin untuk dapat ditentukan jika sebuah perusahaan akan dengan mudah mengambil keuntungan dari peluang yang ada untuk menghindar dari ancaman. Pengamatan internal ini seringkali digunakan sebagai petunjuk oleh seorang analis organisasi dan dilibatkan dengan mengidentifikasi dan membangun sebuah sumberdaya yang dimiliki sebuah organisasi.

Dua karakteristik yang menentukan kesatuan ketahanan perusahaan dalam mempertahankan keunggulan kompetitif (competitive advantage) : Durabilitas dan Imitabilitas.

Durabilitas adalah tingkat yang menunjukkan daya tahan sumber daya dan perusahaan menjadi berkurang atau ketinggalan jaman.

Imitabilitas adalah tingkat yang menunjukkan daya tahan sumber daya dan kemampuan perusahaan (yang diutamakan) dapat diduplikasikan/ditiru oleh perusahaan-perusahaan lain.

Hasil tersebut mampu mengembangkan sumberdaya dalam mempertahankan keunggulan kompetitif (competitive advantage), yang meliputi

1. Transparansi, kecepatan perusahaan pesaing untuk memahami hubungan sumber daya dan mendukung sukses perusahaan.

2. Transferabilitas, kecakapan para pesaing untuk mengumpulkan sumber daya dan dukungan tantangan bersaing.

3. Replikabilitas, kecakapan pesaing untuk menggunakan sumber daya dan meniru kesuksesan.

\section{e. Strategi}

Langkah selanjutnya, Grant menyatakan pilih salah satu strategi yang mengeksploitasi sumber daya dan kapabilitas relatif perusahaan terhadap peluang-peluang eksternal. Untuk itu perlu adanya 
pendekatan terhadap pengamatan dan analisis internal.

Para manajer strategis seharusnya mengenali variebel-variabel dalam perusahaan mereka yang mungkin merupakan kekuatan atau kelemahan yang penting. Sebuah variable merupakan kekuatan apabila menyediakan keunggulan kompetitif. Keunggulan kompetitif adalah sesuatu yang dilakukan perusahaan atau potensi lain yang sudah ada ataupun potensial. Sebuah variable merupakan kelemahan apabila berupa sesuatu yang tidak memiliki kapasitas untuk melakukannya, sementara para pesaingnya memiliki kapasitas tersebut. Dalam mengevaluasi pentingnya variable-variabel tersebut, manajemen harus mengetahui apakah varibel-variabel tersebut merupakan factor strategis internal (strategic internal factors) yaitu kelemahan dan kekuatan khusus perusahaan yang akan membantu menentukan masa depan.

Perusahaan dalam mengukur kekuatan dan kelemahan dapat dilakukan melalui (1). Kinerja masa lalu perusahaan. (2). Pesaing perusahaan dan (3). Industri sebagai satu kesatuan. Apabila suatu variabel (misal keadaan keuangan) secara signifikan berbeda dengan kinerja masa lalu, pesaing kunci perusahaan, atau rata-rata industri, maka variabel tersebut kemungkinan besar merupakan faktor strategis dan harus dilibatkan dalam keputusan-keputusan strategis. Manajer strategis dapat mengamati dan menganalisis variabel internal dapat dilakukan dengan menggunakan pendekatan. Ada dua pendekatan yang dapat dilakukan terhadap pengamatan dan analisis internal, yaitu analisis rantai nilai (value cahin analysis), dan analisis fungsional. Selanjutnya setelah memilih strategi yang mengeksploitasi sumber daya dan kapabilitas relatif terhadap peluang-peluang eksternal maka perlu dilakukan identifikasi kesenjangankesenjangan sumber daya yang harus dipenuhi, inventasi pada pemolesan, penambahan dan peningkatan sumber daya dalam memperbaiki kelemahan-kelemahan.

\section{METODE PENELITIAN}

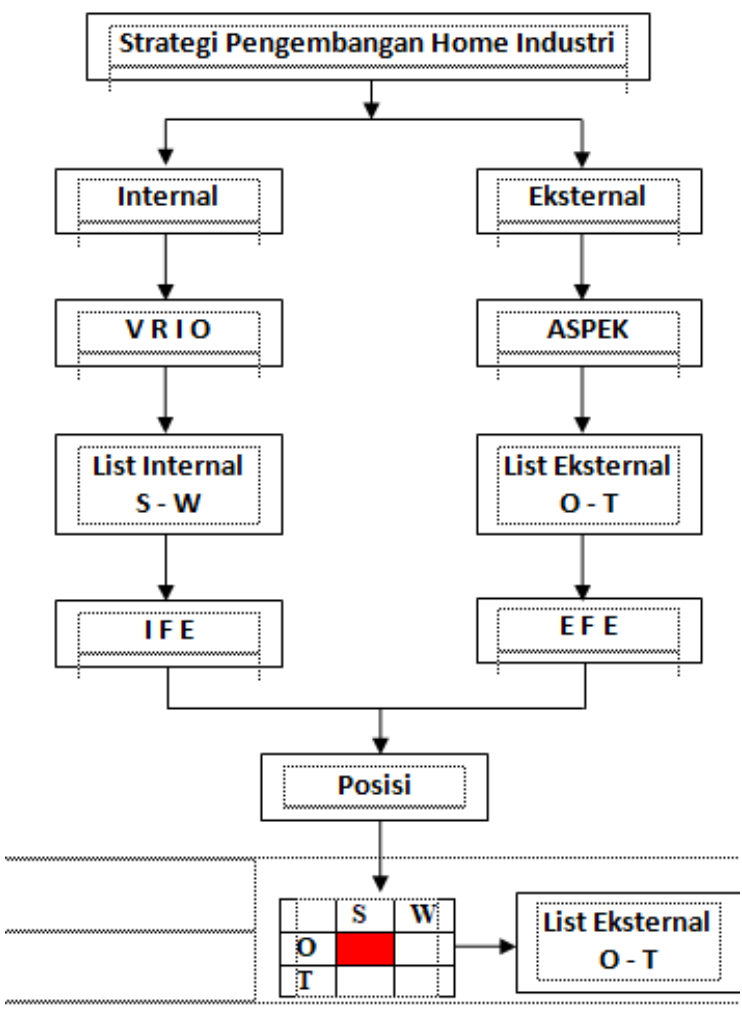

Gambar 1 : kerangka penelitian home industri berbasis sumber daya

\section{a. Tahap penyusunan model strategi}

Model strategi disusun setelah diperoleh informasi posisi strategis dan elemen kunci strateginya dengan menggunakan Analisa SWOT.

\section{b. Pengumpulan Data}

Responden pakar yang digunakan pada penelitian ini berasal dari kalangan pakar industri di daerah yakni : (1) Kepala dinas perindustrian ; (2) Kabid industri; (3) pimpinan industri; (4) karyawan senior dengan pengelaman lebih dari 10 tahun. Responden pakar ditentukan berdasarkan pengalaman, kewenangan, profesionalisme dan integritas terhadap pengembangan home industri di Kab. Rejang Lebong. Data yang digunakan dalam penelitian ini meliputi data primer dan sekunder. Data primer diperoleh melalui: (1) pengamatan langsung; (2) penyebaran kuesioner; (3) wawancara mendalam. Sedangkan data sekunder dikumpulkan dengan cara mempelajari data beberapa home industri. Berikut penjelasan teknik pengumpulan data pada masing-masing tahap :

1. Pengelompokan sumber daya internal home industri 


\section{VOLUME 7 No 12021}

Tabel 1 : Pengelompokan sumber daya internal home industri

\begin{tabular}{|c|c|c|}
\hline aspek & Kekuatan & Kelemahan \\
\hline Modal & $\begin{array}{l}\text { Investasi sarana dan } \\
\text { prasarana }\end{array}$ & $\begin{array}{l}\text { Anggaran pengembangan } \\
\text { karyawan }\end{array}$ \\
\hline Penilaian industri & $\begin{array}{l}\text { Informasi dankriteria } \\
\text { penilaian }\end{array}$ & $\begin{array}{l}\text { Laporan hasil penilaian kinerja } \\
\text { karyawan }\end{array}$ \\
\hline Pimpinan & $\begin{array}{l}\text { pimpinan dengankeahlian } \\
\text { yang sesuai }\end{array}$ & $\begin{array}{l}\text { pimpinan dengan manajerial } \\
\text { inovatif }\end{array}$ \\
\hline Karyawan dan staf & Kerja secara proposional & $\begin{array}{l}\text { Program pengembangan kinerja } \\
\text { karyawan }\end{array}$ \\
\hline Keahlian tenaga kerja & $\begin{array}{l}\text { Mampumelaksanankan } \\
\text { kerja sesuai dengan SOP }\end{array}$ & $\begin{array}{l}\text { Menggunakan informasi dan } \\
\text { pengalaman dalam bekerja }\end{array}$ \\
\hline Pengelolaan industri & $\begin{array}{l}\text { 1. Bekerja sesuai dengan } \\
\text { visi danmisi home } \\
\text { industri } \\
\text { 2. Mengelola sarana dan } \\
\text { prasaranaindustri }\end{array}$ & $\begin{array}{l}\text { System informasi manajemen } \\
\text { yang mendukung industri }\end{array}$ \\
\hline Sarana dan Prasarana, & & $\begin{array}{l}\text { Sarana dan prasarana yang } \\
\text { kurang memadai }\end{array}$ \\
\hline $\begin{array}{l}\text { Proses pembuatan produk } \\
\text { banu }\end{array}$ & $\begin{array}{l}\text { Rencana program } \\
\text { pengembangan produk yang } \\
\text { khas }\end{array}$ & Evaluasi produksi produk banu \\
\hline
\end{tabular}

2. Pengelompokan sumber daya eksternal Home Industri

Tabel 2 : pengelompokan sumber daya eksternal sekolah

\begin{tabular}{|l|l|l|}
\hline \multicolumn{1}{|c|}{ aspek } & \multicolumn{1}{|c|}{ Peluang } & \multicolumn{1}{c|}{ Ancaman } \\
\hline Peraturan dan Regulasi & $\begin{array}{l}\text { Undang-undangkementerian } \\
\text { perindustrian, peraturan } \\
\text { pemerintah danperaturan } \\
\text { daerah }\end{array}$ & $\begin{array}{l}\text { Kurang optimalnya dukungan } \\
\text { dan evaluasi dari stake holders }\end{array}$ \\
\hline $\begin{array}{l}\text { Pemilik industri dan } \\
\text { pengelola }\end{array}$ & $\begin{array}{l}\text { Dukunganpemilik yang } \\
\text { sangatbesarterhadap } \\
\text { pengembanganindustri dan } \\
\text { produk }\end{array}$ & Dana yangterbatas \\
\hline Akses terhadap pembiayaan & $\begin{array}{l}\text { 1. Pembiayaanyang cukup } \\
\text { untukpengembangan } \\
\text { industri }\end{array}$ & Produk dengan biaya mahal \\
\hline Teknologi informasi dan \\
komunikasi
\end{tabular}

\section{c. Pengolahan Data}

Data yang diperoleh baik berupa data primer maupun sekunder diolah melalui beberapa teknik melalui langkah-langkah berikut ini :

\section{Pengolahan data penelitian Waktu dan Tempat Penelitian}

Penelitian dilakukan di Kab. Rejang Lebong mulai dari bulan Januari sampai dengan Agustus 2018, sedangkan kegiatan wawancara responden pakar dilaksanakan pada bulan September 2018.

1. Analisis VRIO Faktor Internal Industri Tabel 3 : Analisis VRIO factor internal Home industri

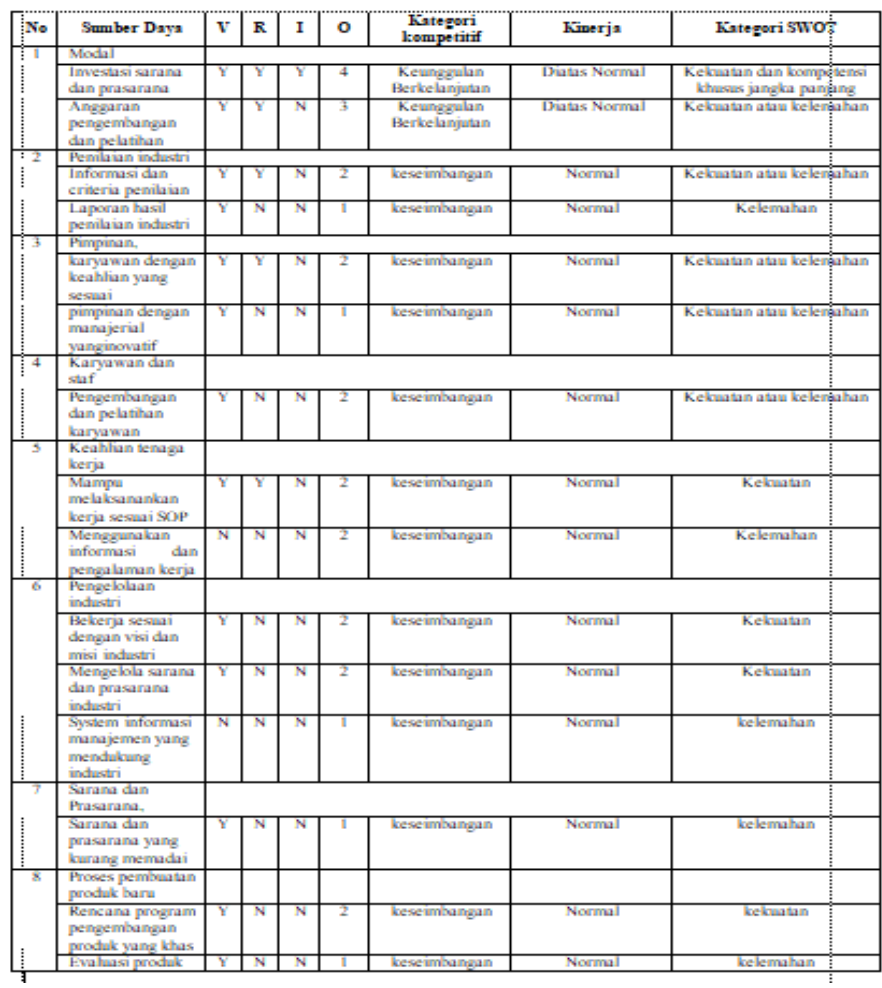

Keterangan : $\mathrm{Y}=$ ya; $\mathrm{N}=$ tidak; $1=$ sumber daya tidak dikelola; 2 = sumber daya cukup dikelola; 3 = sumber daya dikelola; 4 = sumber daya dikelola dengan baik

Setelah melakukan analisis faktor internal industri dengan menggunakan VRIO maka dilakukukan analisis factor eksternal. 
Tabel 4 : Analisis faktor ekternal home industri

\begin{tabular}{|c|l|l|}
\hline$N_{0}$ & \multicolumn{1}{|c|}{ Aspek } & \multicolumn{1}{c|}{ Keterangan } \\
\hline 1 & Peraturan dan Regulasi & $\begin{array}{l}\text { 1. Undang-undang menperindag, peraturan pemerintah dan } \\
\text { peraturan daerah } \\
\text { 2. Kurang optimalnya dukungan dan evaluasi dari stake holders }\end{array}$ \\
\hline 2 & $\begin{array}{l}\text { Pemilik industri dan } \\
\text { pengelola }\end{array}$ & $\begin{array}{l}\text { 1. Dukungan pemilik industri yang sangat besar terhadap } \\
\text { pengembangan home industri } \\
\text { 2. Pelaksanaan pengembangan }\end{array}$ \\
\hline 3 & $\begin{array}{l}\text { Akses terhadap } \\
\text { pembiayaan }\end{array}$ & $\begin{array}{l}\text { 1. Pembiayaan yang cukup untuk pengembangan industri } \\
\text { 2. Menarik investasi dari luar untuk pengembangan }\end{array}$ \\
\hline 4 & $\begin{array}{l}\text { Teknologi informasi dan } \\
\text { komunikasi }\end{array}$ & $\begin{array}{l}\text { 1. Pemanfaatan teknologi informasi dan komunikasi dalam } \\
\text { produksi dan keuangan } \\
\text { 2. Kemudahan mengakses internet }\end{array}$ \\
\hline 5 & $\begin{array}{l}\text { kebijakan } \\
\text { 1. Dukungan pemerintah daerah dalam mengembangkan } \\
\text { industri }\end{array}$ \\
\hline 7 & $\begin{array}{l}\text { 2. Kegiatan pelatihan bagi home industri yang kurang } \\
\text { mendukung }\end{array}$ \\
\hline industri & Lokasi yang strategis dan kemudahan akses lokasi \\
\hline
\end{tabular}

\section{Pengumpulan data penelitian}

\section{Pengelompokan sumber daya internal home industri}

Tabel 1 : Pengelompokan sumber daya internal home industri

Pembuatan alat dilakukan sebisa mungkin sesuai dengan desain. Dalam proses pembuatan dipelukan pengetahuan penggunaan alat-alat pemesinan serta kemungkinan setiap proses produksi yang bisa dilakukan. Dari setiap kemungkinan proses produksi tersebut dipilih yang paling efisien dan tepat untuk pembuatan alat. Dalam pembuatan produk pemilihan alat dan proses pemesinan akan menentukan hasil dari produk yang dibuat.

\section{HASIL DAN PEMBAHASAN}

\section{a. Posisi Strategis Rencana Pengembangan Home Industri}

Faktor internal dan eksternal yang telah ditentukan, selanjutnya akan diolah untuk mengetahui posisi strategis rencana pengembangan industri. Proses selanjutnya adalah :

Tabel 5 : Skor evaluasi faktor internal home industri

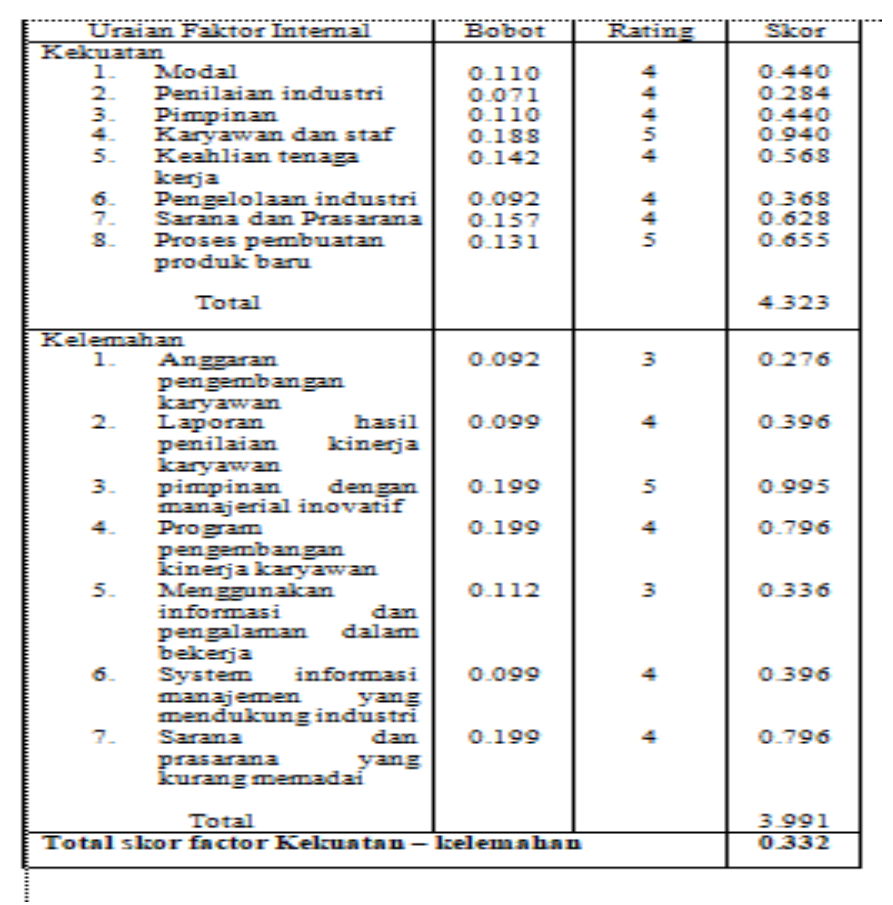

Tabel 6 : Skor evaluasi faktor eksternal home industri

\begin{tabular}{|c|c|c|c|}
\hline Uraian Faktor Internal & Bobot & Rating & Skor \\
\hline \multicolumn{4}{|l|}{ Peluang } \\
\hline \multirow{2}{*}{\multicolumn{4}{|c|}{\begin{tabular}{l|l|l} 
1. Undang-undang & 0.193 & 4
\end{tabular}}} \\
\hline & & & \\
\hline perindustrian, peraturan & \multirow{4}{*}{0.092} & \multirow{4}{*}{3} & \multirow{4}{*}{0.276} \\
\hline $\begin{array}{l}\text { pemeruntah } \\
\text { peraturan daerah }\end{array}$ & & & \\
\hline 2. Dukungan pemilik yang & & & \\
\hline $\begin{array}{l}\text { sangat besar terhadap } \\
\text { pengembangan } \\
\text { dan produk }\end{array}$ & & & \\
\hline 3. Pembiayaan yang cukup & 0.079 & 4 & 0.316 \\
\hline industri & & & \\
\hline 4. Menarik investasi dari & \multirow[t]{2}{*}{0.082} & \multirow[t]{2}{*}{2} & \multirow[t]{2}{*}{0.164} \\
\hline pengembangan & & & \\
\hline $\begin{array}{l}\text { 5. Pemanfaatan teknologi } \\
\text { informasi dan }\end{array}$ & \multirow[t]{2}{*}{0.126} & \multirow[t]{2}{*}{5} & \multirow[t]{2}{*}{0.630} \\
\hline $\begin{array}{l}\text { komunikasi dalam } \\
\text { produksi dan keuangan }\end{array}$ & & & \\
\hline 6. Dukungan pemerintah & \multirow[t]{2}{*}{0.098} & \multirow[t]{2}{*}{4} & \multirow[t]{2}{*}{0.392} \\
\hline $\begin{array}{l}\text { mengembangkan } \\
\text { industri }\end{array}$ & & & \\
\hline $\begin{array}{l}\text { 7. Lokasi yang strategis } \\
\text { dan kemudahan akses }\end{array}$ & 0.116 & 4 & 0.464 \\
\hline $\begin{array}{l}\text { 8. Meningkatnya jumlah } \\
\text { penduduk }\end{array}$ & 0.098 & 4 & \multirow{3}{*}{$\begin{array}{l}0.392 \\
0.468 \\
3.874\end{array}$} \\
\hline 9. Meningkatnya peminat & \multirow[t]{3}{*}{0.117} & \multirow[t]{3}{*}{4} & \\
\hline $\begin{array}{l}\text { terhadap produk yang } \\
\text { khas }\end{array}$ & & & \\
\hline \multicolumn{2}{|l|}{ Total } & & \\
\hline \multicolumn{4}{|l|}{ Ancaman } \\
\hline $\begin{array}{l}\text { 1. Kurang optimalnya } \\
\text { dukungan dan evaluasi } \\
\text { dari stake holders }\end{array}$ & 0.158 & 3 & 0.474 \\
\hline \multirow{4}{*}{$\begin{array}{l}\text { 2. Dana yang terbatas } \\
\text { 3. Produk dengan biaya } \\
\text { mahal } \\
\text { 4. Kemudahan mengakses } \\
\text { internet } \\
\text { 5. Kegiatan pelatihan bagi } \\
\text { home industri yang } \\
\text { kurang mendukung }\end{array}$} & \multirow{2}{*}{$\begin{array}{l}0.178 \\
0.178\end{array}$} & \multirow{2}{*}{$\begin{array}{l}4 \\
5\end{array}$} & 0.712 \\
\hline & & & 0.890 \\
\hline & 0.244 & 3 & 0.732 \\
\hline & 0.082 & 3 & 0.246 \\
\hline $\begin{array}{l}\text { 6. Ketidak mampuan dalam } \\
\text { memenuhi keinginan } \\
\text { konsumen }\end{array}$ & 0.158 & 4 & 0.632 \\
\hline Total & & & 3.686 \\
\hline Cotalsore fa & & & 0.188 \\
\hline
\end{tabular}


dari hasil perhitungan ditentukan posisi pengembangan home industri dengan matrik SPACE

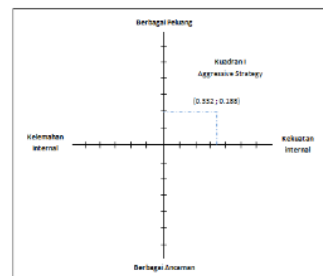

Gambar 2 : Matrik SPACE penentuan strategi

Berdasarkan hasil dari penentuan strategi ada pada kuadran I maka ditetapkan strategi aggresif yaitu memanfaakan kekuatan untuk meraih peluang

\section{b. Perumusan Strategi Pengembangan Home} industri

Strategi pengembangan Home industri disusun dengan mempertimbangkan faktor internal maupun eksternal yang telah disusun. Perumusan strategi pada penelitian ini mempergunakan metode analisis SWOT (selengkapnya disajikan pada Tabel 7).

Tabel 7 : Perumusan strategi pengembangan Home industri

\begin{tabular}{|c|c|c|c|}
\hline & & \multicolumn{2}{|c|}{ Falktor-faletor Intermal } \\
\hline & & Strengths (S) & Wealkness (W) \\
\hline & & $\begin{array}{l}\text { S1 Investasi aspras } \\
\text { S2 Informasi dan penilaian } \\
\text { karyawan } \\
\text { S3 keahlian karyawan } \\
\text { S4 motivasi kerja } \\
\text { S5 Visi dan misi perusahasn } \\
\text { S6 Mengelola sarpras } \\
\text { S7 peralatan kerja yang } \\
\text { memadai } \\
\text { S8 produl yang khas }\end{array}$ & $\begin{array}{l}\text { W1 Anggaran } \\
\text { pelatihan } \\
\text { W2 Laporan hasil } \\
\text { penilaian } \\
\text { W3 Program manajer } \\
\text { inovatif } \\
\text { W4 pengembangan } \\
\text { produk: } \\
\text { W5 Menggunakan } \\
\text { informasi } \\
\text { W6 Sistem informasi } \\
\text { industri } \\
\text { W7 evaluasi kinerja } \\
\text { karyawan }\end{array}$ \\
\hline \multirow{4}{*}{ 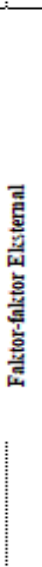 } & Opportunity (O) & SO Strategi & WO Strategi \\
\hline & $\begin{array}{l}\text { O1 Dukungan pemerintah } \\
\text { O2 Dulungan investor } \\
\text { O3 Pembiaysan } \\
\text { pengembangan } \\
\text { O4 Menarik investasi } \\
\text { O5 Pemanfastan telnologi } \\
\text { O6 Dukungan kab. Rejang } \\
\text { lebong } \\
\text { O7 Loksai yang strategis } \\
\text { O8 Jumlah penduduk } \\
\text { O9 Meningkatnya hasil } \\
\text { home industri }\end{array}$ & $\begin{array}{l}\text { Peninglatan sarana dan } \\
\text { prasarana un tulk } \\
\text { mend ukungHome } \\
\text { industri (S1, S2, S03, } \\
\text { O1,O2, O4, O6) } \\
\text { - Memanfaatkan telknologi } \\
\text { untuk mend ulumg } \\
\text { kegiatan prod ulsi (S3, } \\
\text { S7, S8, O5) } \\
\text { Meninglkatkan } \\
\text { kemanupuan dan inovasi } \\
\text { seluruh sumber daya (S5, } \\
\text { S7, O2, O3, O5) } \\
\text { Mengembanglkan produlk } \\
\text { yang khas (S4, S5, O2, } \\
\text { O5) }\end{array}$ & \\
\hline & Treaths $(\mathrm{T})$ & ST Strategi & WT Strategi \\
\hline & $\begin{array}{l}\text { T1 Sinergi stalke holders } \\
\text { T2 Pelaksanam pelatihan } \\
\text { T3 produl: biaya mahal } \\
\text { T4 kegiatan pengembangan } \\
\text { karyawan } \\
\text { T5 Keinginan konsumen }\end{array}$ & & \\
\hline
\end{tabular}

\section{KESIMPULAN}

Perencanaan pengembangan home industri berbasis sumber daya merekomendasikan pengembangan strategis dengan 4 strategi alternatif yaitu :

1. Peningkatan sarana dan prasarana untuk mendukung kegiatan industri

2. Memanfaatkan teknologi untuk mendukung kegiatan

3. Meningkatkan kemampuan dan inovasi seluruh sumber daya

4. Mengembangkan produk yang khas sesuai dengan analisa konsumen

Menentukan langkah untuk menentukan grand strategi dan elemen yang berpengaruh dalam pengembangan home industri.

\section{DAFTAR PUSTAKA}

Gujrati R. 2013. The Role Of Sme's In The Economic Development. Masters International Journal of Management Research and Development 1(1): 86-97.

Marimin. 2004. Teknik dan Aplikasi Pengambilan Keputusan Kriteria Majemuk. Jakarta : Grasindo. 
JURNAL TEKNIK MESIN

ISSN 2252-973X

VOLUME 7 No 12021 